DOI: 10.34015/2523-4552.2019.3.08

УдК 340.15

Добкіна К. Р., кандидат юридичних наук, доцент, декан юридичного факультету Державного університету інфраструктури та технологій e-mail: dobkina@ukr.net ORCID ID: 0000-0003-2627-8871

\title{
ДЖЕРЕЛА ПРАВОВОГО РЕГУЛЮВАННЯ УЧАСТІ ОРГАНІВ ДЕРЖАВНОЇ ВЛАДИ У ЦИВІЛЬНОМУ СУДОЧИНСТВІ (НА ПРИКЛАДІ ДРУГОЇ ПОЛОВИНИ ХІХ СТОЛІТТЯ)
}

Наукова стаття присвячена дослідженню та виокремленню джерел правового регулювання участі органів державної влади у цивільному судочинстві на прикладі другої половини XIX століття.

Ключові слова: цивільне судочинство; учасники цивільного судочинства; органи державної влади; органи прокуратури; Російська імперія.

Научная статья посвящена исследованию и выделению источников правового регулирования участия органов государственной власти в гражданском судопроизводстве на примере второй половины XIX века.

Ключевые слова: гражданское судопроизводство; участники гражданского судопроизводства; органы государственной власти; органы прокуратуры; Российская империя.

Постановка проблеми. Захист прав і свобод людини й громадянина, забезпечення ідей гуманізму є пріоритетними завданнями кожної соціальної, демократичної та правової держави. Історичний розвиток держави і права свідчить, що процес створення та закріплення правових механізмів здійснення правосуддя у цивільних спорах на кожному етапі державотворення характеризувався певними закономірностями. В цілому і цивільний процес, і порядок здійснення окремих процесуальних дій закріплювалися і втілювалися у життя досить неоднозначно за допомогою найрізноманітніших норматив- но-правових актів, серед яких можна виділити не лише закони, але й підзаконні акти, які нерідко суперечили законам та встановлювали нові правила ведення судочинства. Саме за даних умов зароджується окремий вид здійснення судочинства - цивільний процес, який лише в загальних рисах передбачав участь органів державної влади.

Аналіз останніх досліджень і публікацій. Органи державної влади як учасники цивільного судочинства в тій чи іншій мірі були предметом дослідження в роботах різних вчених, серед значної кількості радянських дослідників, необхідно відзна- 
чити найбільш відомих: М. В. Муравйова, А.Ф.Коні, О. В. Васьковського, С. Ю. Кац, О.Г. Маліцького, М. I. Бородіна, I. А. Ходаковського, $\begin{array}{ll}\text { Л. К. Радзієвську, } & \text { В. Й. Сапункова, }\end{array}$ Г. П. Тимченка та ін.

Водночас, дослідження джерел правового регулювання участі органів державної влади у цивільному судочинстві, в тому числі на прикладі другої половини XIX століття науковцями не здійснювалось.

Постановка завдання. Внаслідок чого, метою даної статі $€$ дослідження джерел правового регулювання участі органів державної влади у цивільному судочинстві на прикладі другої половини XIX століття.

Виклад основного матеріалу. Проблеми розвитку цивільного процесуального законодавства в пореформеній Російській імперії неможливо розглядати без врахування судової реформи 1864 року, яка була найбільш радикальною і послідовною серед всіх реформ середини XIX століття.

Потреба в даній реформі не викликала сумнівів. Велике число судових органів 3 нечітко визначеною компетенцією, що існували в дореформений період, призводило до заплутаності судового процесу і процесуальних вимог, а, величезні, іноді десятирічні терміни розгляду цивільних спорів, викликали процвітання хабарництва. Формальна система доказів і письмова форма процесу, були явно застарілими і не відповідали потребам часу.

Міністр юстиції Російської імперії І.Г.Щегловітов відзначав у 1904 році, що «положення кримінального правосуддя до видання судових статутів імператором Олександром II було воістину кричуще. Судова влада була судовою тільки за назвою; організовані суди були не більше, як придаток адміністрації. Писемність процесу, його негласність, панування в ньому теорії формальних доказів, зумовило появу в Росії нового суду - гласного, зі змагальним процесом, 3 незалежними суддями, адвокатурою i присяжними засідателями» [1, с. 2].

Правлячий Сенат був найвищою судовою інстанцією. У його складі було два касаційних департаменти - у цивільних і кримінальних справах, які виконували такі функції:

1) розгляд справ про найбільш небезпечні злочини по першій інстанції за участю або без участі станових представників;

2) перевірка в апеляційному порядку обгрунтованості та законності вироків, винесених без участі станових представників судовими палатами або суддями самого Сенату (сенаторами);

3) перевірка в касаційному порядку законності рішень по цивільних справах і вироків по кримінальних справах, всіх зазначених судових інстанцій, в тому числі вироків, винесених за участю присяжних засідателів або станових представників (в такому порядку не могли перевірятися лише вироки сенаторів, постановлені без участі станових представників). Ця функція вважалася основною.

Велике значення мало створення адвокатури й реорганізація прокуратури. Адвокати ділилися на дві категорії: присяжні повірені, які об'єднуються в корпорації по округах судових палат, і приватні повірені, що працювали при судах і займалися менш значними справами. Прокуратура була позбавлена функції 
загального нагляду, її діяльність обмежилася судовою сферою, в якій здійснювався нагляд за ходом слідства і підтриманням обвинувачення в суді. Підпорядковувалася прокуратура Міністру юстиції [2, с. 53-54].

Таким чином, судова система, створена в процесі реформи 1864 року, містила мало спільних закономірностей із тією системою, яка існувала раніше. Значення судової реформи виходить далеко за рамки сфери судочинства. Ця реформа фактично стала першим кроком на шляху формування системи поділу влади, відокремивши судову владу від адміністративної, а також закріплювала якісно нові принципи ведення цивільного судочинства, які раніше не були відомі, наприклад: гласність і змагальність процесу, участь в процесі представників народу, право на захист.

Проблеми правового регулювання цивільного процесу, в аспекті участі органів державної влади, досліджуваного періоду доцільно розглядати з урахуванням аналізу основних джерел процесуального права. Як справедливо зазначає М. Н. Марченко, джерело права, як одне з фундаментальних понять теорії права, має велике теоретичне і практичне значення [3, с. 210].

Під джерелом позитивного права розуміють форму вираження державної волі, спрямованої на визнання факту існування права, на його формування, зміну або констатацію факту припинення існування права певного змісту. Теорія держави та права визнає такі основні джерела (форми) права: юридичний звичай, закон, підзаконний нормативний акт, судовий прецедент, нормативний договір, правова доктрина.
При цьому важливість і значення цих видів джерел неоднакові.

Один з найбільш видних теоретиків типології правових систем французький вчений Р. Давид вважав, що до 1917 року Російська імперія входила в романо-германську правову сім'ю. Вчений виділяв такі ознаки в підтвердження своєї позиції, як поділ права на приватне і публічне, розмежування матеріального і процесуального права, закон вважався основним джерелом права, а суди відігравали правовстановлюючу роль [4, с. 147].

Незважаючи на це, ряд правників не згодні із Р. Давидом, оскільки зазначали, що важливо враховувати при виділенні й розмежуванні правових систем такі критерії, як походження та історичний розвиток права, своєрідність юридичного мислення, специфіку правових інститутів, походження та способи тлумачення джерел права, ідеологічний вплив на право. 3 огляду на ці критерії, неважко переконатися, що розвиток права в Російській імперії має свої особливості. У зв'язку з цим, заслуговує на увагу точка зору, що можна говорити про цілісну російську правову сім'ю.

Однак її не поділяє більшість сучасних вітчизняних теоретиків. М. Н. Марченко, не заперечуючи своєрідність російської правової системи на сучасному етапі, вказує, що «російське право історично, географічно і навіть духовно стоїть ближче до романо-германського права, аніж до інших правових сімей і систем права [5, с. 322].

На нашу думку, видається цілком обгрунтованою думка, що «загальний тон правової культури Російської імперії був європейським. У 
романо-германську правову сім'ю вона була втягнута об'єктивно, силою власних економічних, соціальних і культурних проблем, але трималася вона там досить відособлено, придивляючись і до інших правових моделей» [5, с. 320].

У сучасній літературі зазначається, що до 1906 року законом вважалося будь-яке веління імператора, оформлене в належному порядку Сенатом. На практиці, очевидно, порядок законотворчості був зворотним - рішення Сенату набували сили закону після обов'язкового затвердження імператором. Як пише професор I. А. Ісаєв, тлумачення законів і вирішення юридичних колізій перебувало у віданні Сенату. Роз'яснення Сенату стали обов'язковими для юридичної практики. Окремі постанови Сенату, затверджені імператором, набували статус законів [5, c. 149].

Під час аналізу джерел права XIX століття виникає важлива проблема відділення законів від підзаконних нормативних актів. Ця проблема в дореволюційному законодавстві не була вирішена. Фахівці, як правило, головною ознакою закону вважали факт його затвердження імператором. Але при цьому необхідно мати на увазі, що багато законодавчих актів часто не мали підпису царя, затверджуючись ним усно. Другою формальною ознакою закону вважалося проходження його через Державну раду. Але повз Державної ради проходили закони, що належали до військового і морського відомств, до церковних справ, до справ Кавказу і Сибіру. Справа ускладнювалася тим, що нерідко в наказах і інструкціях, які затверджувалися через Комітет міністрів або навіть за доповідями окремих міністрів і були, по суті, підзаконними актами, містилися статті, що змінювали або скасовували дію законів, в тому числі, у сфері участі органів державної влади у цивільному судочинстві. Не міг служити надійним формальним критерієм закону і факт поміщення його в Повне зібрання законів або до Зводу законів, оскільки, з одного боку, вони не відрізнялися повнотою, 3 іншого боку, в них нерідко вносили й адміністративні акти, і маніфести, позбавлені правового змісту.

Проте, можна сформулювати, що для цілей даної статті, як і для будь-якого вивчення історії права даного періоду, можна вважати ознакою закону факт його затвердження царем. Ті правові акти, які затверджувалися не імператором, а міністрами, слід відносити до підзаконних нормативних актів.

У середині XIX століття уряд робив спроби вдосконалити законодавчий механізм, вирішити проблему відділення закону від підзаконного нормативного акту, але ці зусилля не увінчалися успіхом. Наслідком невирішеності і нерозв'язності даної проблеми була крайня заплутаність системи законодавства, що збереглася до наших днів, а також можливість легко обходити закони. Відповідно до Основних законів Російської імпеpiï 1892 року закони могли видаватися у вигляді укладень, статутів, установ, грамот, положень, наказів (інструкцій), маніфестів, указів, думок Державної ради і доповідей, удостоєних високого затвердження. Крім того, виходячи за хронологічні рамки дослідження, зазначимо, що після прийняття нової редакції Основних законів Російської імперії від 23 квітня 1906 року законами стали 
вважатися акти, затверджені трьома інстанціями: Державною радою, Державною думою й імператором. Але результатом цього на практиці стало положення, при якому саме укази, тобто підзаконні акти, а не закони, фактично стали основним джерелом російського права. Після 1906 року найпоширенішою формою указу в сфері цивільного судочинства стало затверджене Положення Ради міністрів.

Таким чином, можна відзначити, що основним джерелом процесуального права Російської імперії були закони, які, втім, носили різні назви, оскільки суворої системи термінології і класифікації законодавчих актів встановлено не було.

Як зазначав Г. В. Вернадський, зазвичай розрізняли наступні види законодавчих актів: статути, які встановлювали більш-менш постійні норми в життя окремого відомства для будь-якої певної області матеріального права; регламенти, установи, укази - найбільш поширена форма, які видавалися стосовно вузької сфери суспільного і державного життя. Крім установ, що засновували який-небудь новий державний орган і визначали його правовий статус, в XIX столітті видавалися положення, що визначали порядок діяльності державних та інших установ, а також Тимчасові правила, постанови Ради міністрів, роз'яснення Сенату і думки Державної Ради [6, с. 188].

Таким чином, протягом усього досліджуваного періоду зберігалася множинність форм нормативних актів, що багато в чому визначалося такою особливістю державного устрою, як численність органів верховного управління. Характер правових актів, що були джерелами процесуа- льного та іншого права, багато в чому визначався особливостями їх прийняття.

Законотворчий процес в Російській імперії складався 3 чотирьох основних стадій. Першою, природно, була стадія законодавчої ініціативи формально право просити про видання нового закону було надано всім підданим Російської імперії. На другій стадії відбувалася розробка законопроекту. Нерідко його складанню передувала тривала підготовча робота: докладно вивчався предмет, накопичувався i аналізувався фактичний матеріал, вивчалося відповідне законодавство європейських країн. Матеріали роботи комісії публікувалися. Складений законопроект обговорювали зацікавлені відомства, іноді відбувалося і відкрите обговорення законопроектів шляхом опублікування їх у пресі або передачі становим організаціям. Третя стадія передбачала затвердження законопроекту. Затверджений імператором закон прямував в Сенат для оприлюднення, що було четвертою стадією і необхідною умовою введення закону в дію. Публікація здійснювалася, як правило, публікацією в Зборах узаконень і розпоряджень уряду, але на практиці деякі закони публікувалися відомствами, а не Сенатом [7, с. 209].

В цілому можна констатувати відсутність однаковості в законотворчій діяльності, що породжувало різнорідний характер джерел права i тягло за собою наявність великого числа прогалин і дублювання норм в законодавстві.

До числа головних джерел законодавства в XIX столітті можна віднести ті, які видавалися щорічно із 1830 року, а саме Повне зібрання законів Російської імперії, яке можна 
розглядати як важливе джерело для вивчення історії цивільнопроцесуального права. Але Повне зібрання має і певні недоліки. Перш за все, можна відзначити неповноту змісту, наявність прогалин. Очевидно, відсутність єдиних критеріїв відбору законодавчих актів для публікації в цьому виданні стали причиною наявності прогалин та колізій.

Ще одним важливим джерелом є виданий у 1832 році Звід законів Російської імперії, який був оголошений чинним джерелом права 3 1 січня 1835 року, але згодом перевидавався у 1842 і в 1857 роках. Після цього перевидавалися окремі томи, останній раз у 1912 року, а закони, які ухвалювалися в проміжку між новими виданнями Зводу, містилися в «Продовженнях до Зводу» [8, C. 360].

Оскільки основним джерелом права Російської імперії у досліджуваний період був закон, зазначимо, що основна маса законоположень процесуального характеру містилася в 16 томі Зводу законів Російської імперії. Перша частина цього тому містила Судові статути від 20 листопада 1864 року (основне джерело процесуального права); Правила від 12 липня і 29 грудня 1889 року тощо.

Як справедливо відзначав Є. В. Васьковський, до видання судових статутів діяли процесуальні закони, вміщені у другій частині Х тому Зводу законів, які являли собою «здебільшого механічне поєднання різночасних виданих узаконений, від Уложення 1649 року аж до пізнішого часу» $[7$, с. 86].

Створення судових статутів було складним процесом. У 1848 році Микола II доручив Д. А. Блудову скласти доповідь про необхідні зміни в порядку цивільного судочинства, а у наступному році Д. А. Блудов заявив, що існуюча система потребує докорінного перетворення i представив основні положення запропонованої реформи. На його думку, система цивільного судочинства завдавала шкоди економічному становищу поміщиків. Відсутність ефективного судового захисту підривало основи ведення господарства. Запропонований проект передбачав введення в цивільне судочинство обмеженого змагального процесу. Його можна розглядати як спробу наблизити російське судочинство до європейських зразків i відновити самостійну роль сторін, зведену нанівець у XVII-XVIII століттях. Сторони та їх повірені, які могли б брати участь у процесі, несли відповідальність за представлення своїх свідчень і оскарження судового рішення. Поліція позбавлялася права виробляти слідство у цивільних справах. Виконання судових постанов переходило з компетенції поліції до судових чиновників [9, с. 21].

На думку західного дослідника Р. Уортмана, в реформі цивільного судочинства головною турботою Блудова було сприяння інтересам власників за допомогою лібералізації судових установ [5, с. 21].

Проект реформування цивільного судочинства, розроблений Д. А. Блудовим, зберігав два серйозних пережитки старої системи: урядовий (адміністративний) нагляд за судочинством і становий принцип в правосудді. Таким чином, він не може бути віднесений до послідовнобуржуазного, орієнтованого на злам старої напівфеодальної системи судочинства, в той же час, був орієнтований на досягнення більшої самос- 
тійності суддів-дворян, посилення їх незалежності від роботи судових чиновників-канцеляристів.

Проект Д.А. Блудова зберігав такі риси старої системи, як виборність суддів-дворян, високий майновий ценз для виборців і наявність університетського ступеня в праві для обрання. Таким чином, «проекти Блудова були спробою укомплектувати російську юстицію багатими, розумними та витонченими дворянами й покінчити з образливим для дворянства впливом канцеляристів» [5, с. 22].

У той же час, ряд сучасників досить високо оцінювали проекти графа Блудова. Так, Г. А. Джаншиєв у відомій праці «Основи судової реформи» писав, що в основі проекту Блудова лежали такі принципи: «відділення влади судової від адміністративної, знищення канцелярської таємниці й введення гласності й усності, запровадження змагального процесу та інституту присяжних» $[5$, c. 22].

Проект графа Блудова викликав ряд заперечень, у першу чергу, з формальних підстав. За структурою він складався 3 великої кількості розрізнених нормативно-правових актів, що ускладнювало його практичну реалізацію. Крім того, придумані автором нові численні правила на практиці могли привести до значного збільшення формальностей в судочинстві, ще більше ускладнити його. Зрештою, судова реформа 1864 року була здійснена не за цим проектом.

Характеризуючи судові статути 1864 року як джерела права, на основі яких виник новий суд, $€$. В. Васьковський писав, що «... судові статути були настільки ж гігантсь- ким кроком вперед у сфері судового управління, яким було в області всього взагалі громадянського побуту знищення кріпосного права. Судові статути не вдосконалювали, не поліпшили колишнього, прогнилого судово-процесуального ладу, а створили абсолютно новий, порвавши всякий зв'язок з минулим» $[7$, с. 68].

В указі Олександра II від 20 листопада 1864 року зазначалося: «Розглянувши ці проекти, Ми знаходимо, що вони цілком відповідають бажанням Нашому оселити в Росії суд швидкий, правий, милостивий i рівний для всіх підданих Наших, піднести судову владу, дати їй належну самостійність і взагалі затвердити в народі Нашому повагу до закону, без якої неможливий суспільний добробут» [9, с. 21].

Ухвалення судових статутів фактично оформило остаточний поділ Російського законодавства на матеріальне і процесуальне, закріпивши процесуальні норми в окремих джерелах. При цьому склалася ситуація, коли процесуальні норми були набагато більш досконалими і добре розробленими, ніж норми матеріальні. Зокрема, проект цивільного положення так і не був прийнятий, $\mathrm{i}$ розрізнені, застарілі норми чинного цивільного права різнилися порівняно $з$ сучасними, демократичними цивільно-процесуальними нормами. До числа джерел процесуального права Російської імперії можна віднести також судову практику, оскільки Сенат за своїми роз'ясненнями, встановлював окремі правові норми, що мали обов'язкову силу для всіх підвідомчих йому судових установ.

Висновки. Таким чином, розвиток цивільного процесу в дореволюційній Росії відбувалося в кілька 
основних етапів. Спочатку процесуальні норми були єдині для розгляду як цивільних, так і кримінальних справ. Розгляд цих справ відбувався за єдиними правилами. Поступово, вже в період імперії, відбувається певне відокремлення цивільнопроцесуальних норм і правил, прояв їх специфіки в порівнянні з кримінально-процесуальними нормами. $\mathrm{y}$ цей період зростає сила письмових доказів у цивільних справах. В цілому, в дореформеної Росії не відбулося остаточного поділу процесуального законодавства на цивільний і кримінальний процеси, хоча стійка тенденція до такого поділу намітилася.

У другій половині XIX ст. склалися певні передумови для реформування процесуального законодавства і виділення з його складу відокремленого цивільного процесу. Ці передумови були економічного, політичного, соціального характеру.

Економічною передумовою розвитку цивільного процесуального законодавства стало зростання цивільного обороту та розвиток капіталістичних виробничих відносин. У країні розвивалися промисловість і торгівля, створювалася кредитнобанківська система. Усе це призводило до зростання потреби в справедливому й швидкому вирішенні цивільно-правових справ.

Як важлива передумова реформування системи судочинства може розглядатися і зміна правового ста- новища значної частини населення країни в результаті скасування кріпосного права.

Під соціальними передумовами розвитку цивільного процесу можна розуміти зростання економічноактивного населення, поступове, хоча і повільне, підвищення доходів його певної частини, що, в свою чергу, призводило до зростання числа судових справ цивільно-правового характеру.

У процесі судової реформи 1864 року судова система Російської імперії зазнала кардинальних якісних і структурних змін. Країна отримала новий суд: гласний, змагальний, 3 адвокатурою i присяжними засідателями, а також можливістю брати участь органами державної влади. Такі зміни також сприяли активному розвитку цивільнопроцесуального законодавства по більш демократичного варіанту.

Основним джерелом права в досліджуваний період вважався закон. Відповідно, при реформуванні цивільного процесу нові правові норми закріплювалися в законодавчих джерелах, серед яких головне місце займав Статут цивільного судочинства 1864 року. Реформування ж цивільного процесуального законодавства Російської імперії в другій половині XIX століття стало закономірним фактом, обумовленим наявністю певних передумов і розвитком вітчизняного права.

\section{Список використаних джерел}

1. Щегловитов И. Г. К сорокалетию судебных уставов 20 ноября 1864 года. Вестник права. 1904. №9. С. 2-3.

2. Чечот Д. М. Актуальные проблемы теории и практики гражданского процесса. Ленинград : Издательство Ленинградского университета. 1979. 67 с.

3. Победоносцев К. П. Сочинения. Санкт-Петербург : Наука. 1996. 508 с. 
4. Хорошилов А. Н. Проблемы исследования российской правовой системы как объекта общей теории права. Ученые записки МГСУ. 1997. № 1. С. 143-148.

5. Комаров Н. И., Пашенцев Д. А., Пашенцева С. В. Очерки истории права Российской империи (вторая половина XIX - начало XX века). Москва : Статут, 1996. 346 c.

6. Вернадский Г. В. Очерк истории права Русского государства XVIII-XIX вв. (Период империи). Прага : Легиография. 1924. 166 с.

7. Васьковский Е. В. Учебник гражданского процесса. Москва : Госюриздат, 1917. 327 c.

8. Ерман Л. К. Интеллигенция в первой русской революции. Москва : Госюридзат, 1966. 373 с.

9. Шакарян М. С. Участие в советском гражданском процессе органов государственного управления. Лекция для студентов. Москва : МГУ, 1978. 36 с.

\section{References}

1. Sheglovitov, I. G. (1904). K sorokaletiyu sudebnyh ustavov 20 noyabrya 1864 goda. Vestnik prava, 9, 2-3 [in Russian].

2. Chechot, D. M. (1979). Aktualnye problemy teorii i praktiki grazhdanskogo processa. Leningrad: Izdatelstvo Leningradskogo universiteta [in Russian].

3. Pobedonoscev, K. P. (1996). Sochineniya. Sankt-Peterburg: Nauka [in Russian].

4. Horoshilov, A. N. (1997). Problemy issledovaniya rossijskoj pravovoj sistemy kak obekta obshej teorii prava. Uchenye zapiski MGSU, 1, 143-148 [in Russian].

5. Komarov, N. I., Pashencev, D. A., Pashenceva, S. V. (1996). Ocherki istorii prava Rossijskoj imperii (vtoraya polovina XIX - nachalo XX veka). Moskva: Statut [in Russian].

6. Vernadskij, G. V. (1924). Ocherk istorii prava Russkogo gosudarstva XVIII-XIX vv. (Period imperii). Praga: Legiografiya [in Russian].

7. Vaskovskij, E. V. (1917). Uchebnik grazhdanskogo processa. Moskva: Gosyurizdat [in Russian].

8. Erman, L. (1966). Intelligenciya v pervoj russkoj revolyucii. Moskva: Gosyuridzat [in Russian].

9. Shakaryan, M. S. (1978). Uchastie v sovetskom grazhdanskom processe organov gosudarstvennogo upravleniya. Moskva: MGU [in Russian].

K. Dobkina, PhD in Law, Associate Professor, Dean of the Faculty of Law, the State University of Infrastructure and Technologies

e-mail: dobkina@ukr.net; ORCID ID: 0000-0003-2627-8871

\section{Sources of law about participation public authorities in civil procedure (on the second half of the XIX century)}

The scientific article is devoted to a research and allocation of sources of legal regulation of participation of public authorities in civil legal proceedings on the example of the second half of XIX of a century.

The author specified that problems of legal regulation of civil process, in aspect of participation of public authorities of the studied period it is expedient to consider taking into account the analysis of the main sources of procedural law and it is established that to 1906 any command of the emperor issued as appropriate by 
the Senate was considered as the law. In practice, obviously, the order of lawmaking was the return - the decision of the senate acquired by law forces after the obligatory approval by the emperor.

It is proved that laws which, however, carried different names as the strict system of terminology and classification acts it was not established, for example were the main source of procedural law of the Russian Empire: charters, regulations, institutions, decrees and so forth.

During all studied period, the plurality of forms of regulations remained that in many respects defined by such feature of state system as plurality of bodies of the Supreme management. Features of their acceptance defined the nature of legal acts that were sources of procedural and other law, in many respects.

In the course of judicial reform of 1864, the judicial system of the Russian Empire underwent cardinal high quality and structural changes. The country received new court: public, competitive, with legal profession and jurors and an opportunity to participate public authorities. Such changes also contributed to the active development of the Civil and procedural legislation on more democratic option.

During the studied period, the law considered as the main source of the right. Respectively, when reforming civil process new precepts of law were enshrined in legislative sources among which the main place taken by the charter of civil legal proceedings of 1864. Reforming of the civil procedural legislation of the Russian Empire in the second half of the 19th century became natural to the fact, the caused existence of certain prerequisites and development of the domestic right.

Keywords: civil procedure; participants in civil proceedings; public authorities, prosecutors; The Russian Empire. 